\title{
An investigation into the usage of mobile phones among technical and vocational educational and training students in South Africa
}

\begin{tabular}{|c|c|}
\hline \multicolumn{2}{|c|}{$\begin{array}{l}\text { Authors: } \\
\text { Herring Shava }{ }^{1} \\
\text { Willie Chinyamurindi }^{1} \\
\text { Anathi Somdyala }^{2}\end{array}$} \\
\hline \multicolumn{2}{|c|}{$\begin{array}{l}\text { Affiliations: } \\
{ }^{1} \text { Department of Business } \\
\text { Management, University of } \\
\text { Fort Hare, South Africa }\end{array}$} \\
\hline \multicolumn{2}{|c|}{$\begin{array}{l}\text { Business Management Unit, } \\
\text { East London Management } \\
\text { Institute, South Africa }\end{array}$} \\
\hline \multicolumn{2}{|c|}{$\begin{array}{l}\text { Corresponding author: } \\
\text { Willie Chinyamurindi, } \\
\text { chinyaz@gmail.com }\end{array}$} \\
\hline \multicolumn{2}{|c|}{$\begin{array}{l}\text { Dates: } \\
\text { Received: } 21 \text { Oct. } 2015 \\
\text { Accepted: } 02 \text { June } 2016 \\
\text { Published: } 25 \text { Aug. } 2016\end{array}$} \\
\hline \multicolumn{2}{|c|}{$\begin{array}{l}\text { How to cite this article: } \\
\text { Shava, H., Chinyamurindi, W. \& } \\
\text { Somdyala, A., 2016, 'An } \\
\text { investigation into the usage } \\
\text { of mobile phones among } \\
\text { technical and vocational } \\
\text { educational and training } \\
\text { students in South Africa', } \\
\text { South African Journal of } \\
\text { Information Management } \\
\text { 18(1), a716. http://dx.doi. } \\
\text { org/10.4102/sajim.v18i1.716 }\end{array}$} \\
\hline \multicolumn{2}{|c|}{$\begin{array}{l}\text { Copyright: } \\
\text { @ 2016. The Authors. } \\
\text { Licensee: AOSIS. This work } \\
\text { is licensed under the } \\
\text { Creative Commons } \\
\text { Attribution License. }\end{array}$} \\
\hline \multicolumn{2}{|l|}{ Read online: } \\
\hline 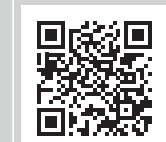 & $\begin{array}{l}\text { Scan this QR } \\
\text { code with your } \\
\text { smart phone or } \\
\text { mobile device } \\
\text { to read online. }\end{array}$ \\
\hline
\end{tabular}

Background: Information and Communication Technologies (ICTs) are gaining popularity in South Africa; this includes the use of mobile phones and the Internet. Mobile phones also seem to be popular with the student cohort of the South African population, especially for communication purposes. Empirical evidence affirms the importance of mobile phones to this cohort, including the need to research further how these groups use and experience such devices.

Objectives: This study seeks to provide an understanding of how mobile phone features, the motivation to use and time spent on a mobile phone influence behavioural intention to use mobile phones among a sample of technical and vocational educational and training (TVET) students in the Eastern Cape Province of South Africa.

Method: A survey was carried out with 161 TVET students through a self-administered questionnaire completed by each respondent. Pre-testing and pilot testing of measures were conducted using a sample of final-year students using mobile phones who fit the same characteristics as the intended sample. To arrive at findings, data analysis was undertaken through the Chi-square test.

Results: Descriptive results of the study reveal that the majority of mobile phones owned by TVET students were in the category of smartphones, bearing modern features that facilitate instant messaging, exchange of data and information as well as speedy access to information via the Internet.

Conclusion: Inferential results of the study indicate that the more features a mobile phone has, the higher the desire to make use of the phone for communication purposes. Furthermore, motivation and time were found to play insignificant roles in influencing student utilisation of mobile phones for communication purposes.

\section{Introduction}

The use of Information and Communication Technologies (ICTs) has become popular in modern society, and the mobile phone has become one of the most 'ubiquitous' devices found in most parts of the world (Li et al. 2012:469). This is a stark contrast to earlier held views of mobile phones as gadgets that would not attract much ownership (Karim, Darus \& Hussin 2006). One cohort popular for using such ICTs includes young adults and students. Skiba's study (2014) focusing on connectivity through applications designed for mobile devices found that $79 \%$ of tertiary-level students own the newly innovated smartphones. Head and Ziolkowski (2012:2331) not only affirm the importance of mobile phones to this cohort but also the need to research how these groups 'value the feature richness of their devices'. This appears to be a consistent view among scholars attributing the need to investigate the impact technology may have in different communities (Chen \& Katz 2009; Katz 2006). Skiba (2014) further suggests that youths attending tertiary institutions value interaction to the extent that $70 \%$ were found to be utilising mobile phones during class sessions.

This study seeks to extend the knowledge base of mobile phone usage and student behaviour in two important ways. Firstly, this study seeks to establish what students are using their mobile phones for. Secondly, this study seeks to understand individual usage of the mobile phone and its relation to phone features and individual-specific factors such as motivation and time. The findings of the study have important implications for educators, marketers and communication researchers involved in studying the student market and their communication patterns. 
The rest of the study is organised in the following manner: discussion of the background on technical and vocational educational and training (TVET) and review of literature on mobile phone usage and student population leading to the study's hypotheses. Thereafter, the research methodology, results, discussion and implication of the study as well as limitations are discussed. The last sections focus on areas for future research and the study's conclusion.

\section{Technical and vocational educational and training sector}

The TVET sector is mapped in such a way that each curriculum on offer is based on a job title, thereby playing a critical role in the development of a country through the production of skilled and semi-skilled manpower (Chua \& Jamil 2012). TVET colleges in South Africa emerged from the famous public Further Education and Training (FET) college system. These FETs were established to help develop practical vocational skills in sectors such as agriculture, arts and culture, business, commerce and management, education, training and development, engineering, manufacturing and technology, services, building construction and security (Fisher, Jaff, Powell \& Hall 2003).

Within higher education, calls have been made for research aimed at furthering understanding of the adoption and utilisation of technology (Chinyamurindi \& Shava 2015; Hsiao \& Yang 2011), especially within institutions and among students given the varied popularity of technology not just for learning purposes (Park 2009).

\section{Mobile phones and the student population}

Students have been found to have strong consumption behaviour with regard to their usage of mobile phones (Jamal et al. 2012). Such a practice is believed to be universal and cuts across various barriers, thus making students an important target market (Jurisic \& Azevedo 2011). Prior research has revealed that mobile phone usage enhances a student's learning experience and increases a student's attention to school work and participation in learning activities (Eteokleous \& Ktoridou 2009).

The popularity of mobile phones among the student market could be due to a number of reasons. Chen and Katz (2009) found the popularity of the mobile phone to be due to students' need to communicate with family while they are away studying. Baysal, Sahenk and Hazneci (2010) attribute mobile phone features to the popularity of mobile phones. This includes features such as making voice calls, sending messages, live chat, playing music, playing video games, the Internet and telephone banking services. The presence of such features makes mobile phones influential in everyday communication (Pourrazavi et al. 2014) among younger generations (Hakoama \& Hakoyama 2011). All this has led to the emergence of the smartphone - a phone that has the ability to not only enhance interpersonal communication but also incorporate a range of multimedia tools (Ting et al. 2011).

Furthermore, mobile phones appear popular among students given their ability to link users to social networks for the purpose of human interaction (Walsh, White \& Young 2010). Others attribute factors such as convenience, mobility, safety and networking as contributing significantly to the popularity of mobile phones (Ling 2004).

\section{Determinants of mobile phone usage}

This section presents the key theoretical underpinnings of intention to use information technology products and services, focusing on intention to use within the mobile phone context. A focus on factors that influence the adoption of technology is argued as important, not just for the full utilisation, but also acceptance of the technology (Hsiao \& Yang 2011). Furthermore, it may help grasp a picture not just into usage of mobile phones but also the decision processes users of such technology go through. This section pays attention first to the dependent variable, which is behavioural intention to use (BIU).

\section{Behavioural intention to use}

An important theoretical consideration specific to the utilisation of technology is the Technology Acceptance Model (TAM) (Venkatesh \& Davis 2000). This model consists of two beliefs, namely: perceived usefulness and perceived ease of use of the application. These two determine attitudes towards the adoption of a new technology. The attitude towards adoption depicts the prospective adopter's positive or negative orientation and/or behaviour towards adopting a new technology (Venkatesh \& Davis 2000). Usage could also be influenced by an individual's perception of the ability to use the technology (Compeau \& Higgins 1995). Subsequently, all these elements of TAM can serve as predictors of human behaviour (Fishbein \& Ajzen 1975; Lee \& Lehto 2013) or BIU, thus resulting in TAM being seen as a useful predictor in explaining human behaviour concerning technology acceptance (Agundo-Peregrina, Hernández-García \& Pascual-Miguel 2014; Chen, Li \& Li 2011; Chinyamurindi \& Louw 2010; Chinyamurindi \& Shava 2015; Saadé, Nebebe \& Tan 2007).

The TAM is built around the theory of reasoned action (TRA) (Fishbein \& Ajzen 1975), which suggests that individual behaviour is initiated by the intention to perform a particular task. The result of this is that individual behavioural intention determines one's attitude and subjective norms regarding the behaviour in question (Fishbein \& Ajzen 1975). The TRA also posits that intention to act determines behaviour, and a causal link is believed to exist between the two (Venkatesh \& Davis 2000). The attitude-behavioural intention relationship, as espoused in the TAM constructs, assumes that all intentions to use technology are equal and can be formed on the basis of positive usage of the technology. This study, therefore, seeks 
to test if mobile phone features, motivation and time (all independent variables) can be associated with the BIU (dependent variable) mobile phones.

\section{Mobile phone features}

Research indicates that the amount of features on a mobile phone is related to the lifetime of the mobile phone (Li et al. 2012). Added to this, empirical evidence shows successful usage or adoption of a technology to be dependent on its full utilisation (Ilechukwu 2013; Nwogu, Udoye \& Oguejiofor 2014). In essence, the more features a mobile phone has, the more time the phone may remain in the hands of the user. This appears to be supported by the economic theory suggesting that product features and attributes are linked to consumer demand given the additive utility function (Lancaster 1971). Building on the previous statement, Head and Ziolkowski (2012) suggest that there is a positive relationship between mobile phone features and consumer usage of the product. From a marketing point of view, this may create a competitive advantage that helps phone manufacturers stand out from their competitors (Mukherjee \& Hoyer 2001).

Furthermore, research shows the mobile phone to be more popular for leisure than for school- or work-related causes (Lepp et al. 2013). Economicides and Grouspoulou (2009) found that students tend to consider the following features important: battery life, mp3 player, video camera, Bluetooth and chatting sites. The features favoured appear to be those that encourage interactivity, simplicity and the availability of up-to-date information (Wanajak 2011). In support of the previous notion, a South African study undertaken to determine mobile application and/or features preferred by university students found that features that provide students with access to information and entertainment were downloaded more than other features (Potgieter 2015).

Given that the majority of mobile phone features appear to support a leisure cause also found to be popular among students (Mannell 2007), it can be expected that mobile phone features will be related to BIU. The thinking here could be that a high number of mobile phone features reflect the phone's expanded functionality (Lepp et al. 2015). Therefore, it is expected that:

Hypothesis 1: An association can be found between mobile phone features and BIU.

\section{Motivation}

Motivation refers to 'the reasons underlying behaviour' (Guay et al. 2010:712) and directs humans (Gredler, Broussard \& Garrison 2004). Motivation can be viewed as influencing individual behaviour to use mobile phones. Individuals should be willing and able to use these technologies by accepting them as this will lead to improved efficiency (Keeton 2008). In the context of this study, motivational factors are those that move individuals to use their phones (Van Biljon 2006). The thinking here could be that individual motivation needs to exist as a fundamental technology adoption requirement (Qualasvirta 2005).

Bandura (1986) highlighted that motivation, either as external (observing others) or internal (individual self-efficacy), affects intention and adoption of behaviour. This view has been supported in a number of empirical studies (Peters et al. 2006; Wang, Lin \& Luarn 2006). In some studies (Li et al. 2012), the motivation to change a mobile phone was motivated by the phone being damaged. In essence, lack of functionality resulted in no usage of the phone and, in turn, created no further motivation for using such a device.

However, using the choice task complexity theory (Johnson \& Payne 1985), motivation and time can be influenced by complexity of the mobile phone as a physical product and its features. The thinking here could be that the greater the product feature and its complexity, the more consumer effort needed. In essence, Wright (1975) theorised that consumers usually wish to minimise decision efforts. Resultantly, mobile phones that come with features that require much effort and time may be avoided because of their complexity (Dellaert \& Stremersch 2005) and trigger anxiety or stress (Mick \& Fournier 1998). This can often lead to feature fatigue when too many features make a product overwhelming, thereby causing dissatisfaction (Thompson, Hamilton \& Rust 2005).

An attitude towards mobile phone usage may be formed as a result. Using the TRA (Ajzen \& Fishbein 1980) based on the attitude (positive or negative), this may affect intention to perform a behaviour. The presence or absence of motivation has been found to influence satisfaction or dissatisfaction (Zhang \& Von Dran 2000). In some cases, lack of motivation to use technology can often result in resistance to use the technology based on user perceptions (Desmet \& Parente 2012). Thus, the usage of mobile phones can serve as a motivational utility value in meeting individual needs (Jokela 2004; Kang 2014). Given this, it can be expected that:

Hypothesis 2: An association can be found between motivation and BIU.

\section{Time}

The mobile phone is an anytime and anywhere tool, thus boosting the tendency to do things discreetly as well as openly. The Internet has removed a geographical boundary, which means students have an abundance of information at their disposal accessed at their convenience (Caronia \& Caron 2004). Among students, time limitations have been found to affect how students use mobile phones (Lightner, Benander \& Kramer 2008). However, the Salesforce Marketing Cloud (2014) reports that people between the ages of 18 and 25, on average, utilise phones for 5.2 hours per day. The majority of TVET students in South Africa fall within this age category. Therefore, it is expected that:

Hypothesis 3: An association can be found between time and BIU. 
The hypothesised relationships are described graphically in Figure 1. The research seeks to answer the following questions: (1) What are the salient factors that influence the BIU mobile phones among a sample of TVET students in South Africa? (2) What are the sampled TVET students using mobile phones for?

\section{Research methodology}

This section highlights the research paradigm, research design, research respondents, measuring instrument, the research procedure and statistical analysis adopted in this study.

\section{Research paradigm}

Researchers adopted the post-positivist approach. To successfully undertake this research, researchers recognised that 'all cause and effect is a probability that may or may not occur' (Creswell 2013:23-24). The post-positivist approach is a shift from traditional positivism (Philips \& Burbules 2000). Post-positivists argue that it is rather unlikely for an individual to be absolutely positive about claims that other people make in respect of knowledge, specifically when human behaviour is the subject under scrutiny as is the case in this study (Creswell 2014; Philips \& Burbules 2000).

\section{Research design}

The study adopted the survey research design. Survey research enables the researcher to gather quantitative data with regard to 'trends, attitudes or opinions' by examining a subset of a population, which is the case in this study (Creswell 2014:13). To achieve this, a self-administered questionnaire was used, given that it allowed for investigating the associations between the determinants and BIU mobile phones within the sample. Furthermore, questionnaires were a cost-effective method, thereby allowing a wider reach (Jack \& Clarke 1998). Finally, responses were gathered in a standardised manner as the study adopted existing TAM measures.

\section{Research respondents}

The sample consisted of 161 TVET students studying in institutions located in East London and consisted of 76 male participants $(n=76)$ and 85 female participants $(n=85)$. The respondents responded to a 34-item self-administered questionnaire. The questionnaire was made available to the

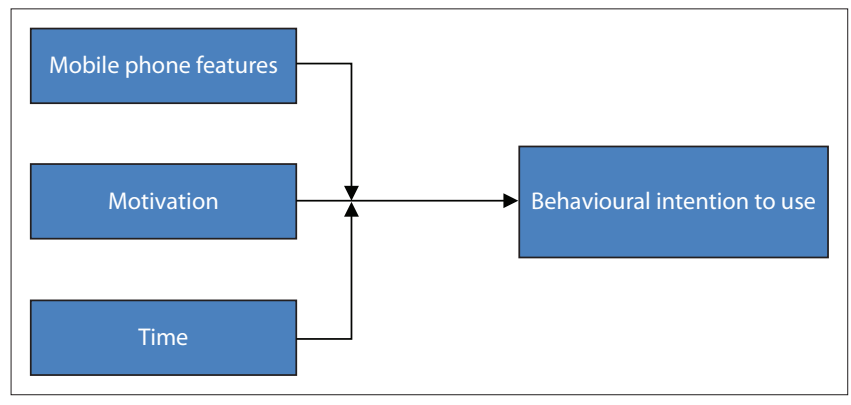

FIGURE 1: Theoretical model. students through a trained data collector employed for this project and a former student of the TVET College. Students were first asked to respond to some descriptive questions and thereafter to a series of questions on a five-point Likert scale.

\section{Measuring instrument}

In an attempt to ensure content validity of the scales, items represented the concept of which generalisations were to be made. The researchers selected items that were either mainly adapted from previous studies or from the previous application of the TAM (Compeau \& Higgins 1995; Davis 1989; Kyobe \& Shongwe 2011; Ong \& Lai 2006; Venkatesh \& Davis 1996). Validated items adapted from prior studies were used to measure mobile phone features, time, motivation and BIU.

In terms of the reliability of the measure, sufficient reliability was found (mobile phone features - 0.71; time - 0.70; motivation - 0.73 and BIU - 0.77). The reliability of the measures in this study showed sufficient reliability as per the recommended threshold of 0.70 (Streiner 1993). Pre-testing and pilot testing of measures were conducted using a sample of final-year students using mobile phones who fit the same characteristics as the intended sample at a private TVET College in East London. Academics from the education and computer science fields from the University of Fort Hare (Alice and East London Campuses) were also consulted to give their input on the study instrument. The questionnaire items were modified to make them relevant to the context of the intended study based upon the feedback.

\section{Research procedure}

Permission was granted from the participating TVET College, and relevant ethical clearance was obtained. The research assistant was assisted by a former TVET student in collecting data. The former TVET student was also trained and briefed on the study and expectations. The research assistant and the former TVET student approached potential respondents and introduced themselves and stated the objectives of the study. Potential respondents were informed of the expectations from them and the recourse (including their rights) they could exercise if they wanted to withdraw from the study. Participation in the research was voluntary, and this was communicated to the respondents through the research assistant; respondents could withdraw at any time. To ensure anonymity and confidentiality, participants were informed not to endorse their names, signatures or nicknames on questionnaires.

\section{Statistical analyses}

Data analysis was carried out using IBM Statistical Package for Social Sciences Version 22.0. Cronbach's alpha coefficients $(\alpha)$ were used to assess the internal consistency of the measuring instruments (Clark \& Watson 1995). Statistical analysis also involved generating a descriptive picture 
concerning the phenomena under study. Inferential statistics were used to determine the association between the dependent and the independent variables. Inferential statistics assist in generalising findings from the sample to the larger population (Wiid \& Diggines 2013). Relying on inferential statistics further helped the researchers to come to conclusions from observations about the population of the study (Babbie 1992). The study data did not violate the assumption of normality. Using the Kolmogorov-Smirnov statistic, a non-significant value of 0.2 larger than 0.05 was found (Field 2013). Furthermore, the Chi-square test of independence, a parametric statistic was used to statistically analyse the study's hypotheses (Pallant 2010).

\section{Results}

Furthermore, the research sought to establish, through descriptive statistics, what features did the mobile phones for TVET students have. Table 1 summarises the results. Table 2 reveals what TVET students used their mobile phones for based on the features on their phones.

Table 1 indicates that the majority of mobile phones were in the category of smartphones and bearing modern features that facilitate instant messaging (chat features). The majority of these phones also had a camera, Bluetooth and GPS applications installed. Most importantly, Table 1 indicates that the majority of mobile phones were equipped with Internet browsers enabling TVET students' easy and speedy access of information via the Internet.

Besides traditional mobile uses such as voice calling and messaging, Table 2 summarises other major uses of mobile phones by TVET students. The study's findings reveal that

TABLE 1: Mobile phone features.

\begin{tabular}{|c|c|c|}
\hline Descriptive statistics & Frequency & $\%$ \\
\hline \multicolumn{3}{|l|}{ Phone type } \\
\hline Smartphone & 150 & 93 \\
\hline Non-smartphone & 11 & 7 \\
\hline \multicolumn{3}{|l|}{ Chat feature on phone } \\
\hline Yes & 133 & 83 \\
\hline No & 28 & 17 \\
\hline MMS & & 0 \\
\hline Yes & 134 & 83 \\
\hline No & 27 & 17 \\
\hline \multicolumn{3}{|l|}{ Internet on phone } \\
\hline Yes & 159 & 99 \\
\hline No & 2 & 1 \\
\hline \multicolumn{3}{|l|}{ Camera on phone } \\
\hline Yes & 159 & 99 \\
\hline No & 2 & 1 \\
\hline \multicolumn{3}{|l|}{ Bluetooth on phone } \\
\hline Yes & 158 & 98 \\
\hline No & 3 & 2 \\
\hline \multicolumn{3}{|l|}{ GPS on phone } \\
\hline Yes & 126 & 78 \\
\hline No & 35 & 22 \\
\hline \multicolumn{3}{|l|}{ Live TV on phone } \\
\hline Yes & 38 & 24 \\
\hline No & 123 & 76 \\
\hline
\end{tabular}

besides voice calling and messaging, the majority of students utilise mobile phones for chatting purposes. Chatting is effectively carried out through various phone features and/ or applications compatible to different phone models. The applications range from Facebook, BBM to WhatsApp among others. TVET students also use mobile phones for entertainment purposes. The majority of phones have music player applications installed. For the user to use the music player feature, he or she has to upload music and have it stored within. However, other Internet sites or applications such as YouTube and iTunes enable the user to access music online for entertainment purposes without uploading it, thereby making entertainment the second major use of mobile phones among TVET students. From Table 2, emailing became the third major use of mobile phones among TVET students. Emailing is predominantly carried out through Gmail and Yahoo mail. Moreover, mobile phones are being used to gather information on the Internet for various purposes, depending on the lifestyle of the mobile phone owner. Some use the mobile phone to access weather updates and for comparing product and/or service prices, and others use the mobile phone to gather information on health-related issues, thus making use of the WebMD site.

In testing hypotheses 1,2 and 3, the Chi-square test was used. Table 3 reflects the results of the analyses.

To test hypothesis 1 , the association between mobile phone features and BIU, a Chi-square test for independence indicated a statistically significant association between mobile phone features and BIU mobile phones, as shown in

TABLE 2: Major uses of mobile phones among TVET students.

\begin{tabular}{|c|c|c|}
\hline Category of use & $\begin{array}{l}\text { Application and/or feature } \\
\text { and/or site }\end{array}$ & Frequency \\
\hline \multirow[t]{9}{*}{ Social media } & Facebook & 104 \\
\hline & Twitter & 38 \\
\hline & Instagram & 14 \\
\hline & BBM & 69 \\
\hline & WhatsApp & 125 \\
\hline & 2go & 8 \\
\hline & WeChat & 9 \\
\hline & Mxit & 11 \\
\hline & Skype & 3 \\
\hline \multirow[t]{6}{*}{ Entertainment } & Shazam & 4 \\
\hline & YouTube & 36 \\
\hline & iTunes & 3 \\
\hline & Zonkewap & 12 \\
\hline & Kasi mp3 & 3 \\
\hline & Toxicwap & 17 \\
\hline \multirow[t]{2}{*}{ Online shopping } & Bid or Buy & 6 \\
\hline & Gumtree & 8 \\
\hline \multirow[t]{3}{*}{ Emailing } & Gmail & 15 \\
\hline & Yahoo mail & 8 \\
\hline & Webmail & 6 \\
\hline \multirow[t]{6}{*}{ General Internet search } & Online news & 3 \\
\hline & WebMD & 2 \\
\hline & Wiki answers & 2 \\
\hline & Price check & 3 \\
\hline & Bodybuilder & 4 \\
\hline & Weather & 3 \\
\hline
\end{tabular}


TABLE 3: Chi-square tests

\begin{tabular}{lccc}
\hline Variables & $\begin{array}{c}\text { Hypothesis 1: } \\
\text { MPF -> BIU }\end{array}$ & $\begin{array}{c}\text { Hypothesis 2: } \\
\text { M }>\text { BIU }\end{array}$ & $\begin{array}{c}\text { Hypothesis 3: } \\
\text { T }>\text { BIU }\end{array}$ \\
\hline Pearson Chi-square & $174.989^{\mathrm{a}}$ & $39.748^{\mathrm{b}}$ & $67.527^{\mathrm{c}}$ \\
$\begin{array}{l}\text { Likelihood ratio } \\
\begin{array}{l}\text { Linear-by-linear } \\
\text { association }\end{array}\end{array}$ & 133.21 & 44.134 & 68.996 \\
$\begin{array}{l}\text { Number of valid } \\
\text { cases }\end{array}$ & 1.286 & 0.416 & 0.292 \\
$\begin{array}{l}\text { Asymptotic } \\
\text { Significance (2 sided) }\end{array}$ & 0.012 & 161 & 161 \\
\hline
\end{tabular}

MPF, Mobile phone features; BIU, Behavioural intention to use; M, Motivation; T, Time

a, 166 cells $(98.8 \%$ ) have expected count less than 5 (the minimum expected count is 0.1 ) b, 61 cells $(84.7 \%$ ) have expected count less than 5 (the minimum expected count is 0.1 ) c, $75(89.3 \%)$ have expected count less than 5 (the minimum expected count is 0.1 ).

Table $3, X^{2}(n=161)=174.989, p=0.012$. Therefore, hypothesis 1 stating that a significant association can be found between mobile phone features and BIU, is supported. The conclusion here is that the more mobile phone features present on the phone, the higher the BIU the phone for communication purposes. With regard to hypothesis 2 , the aim was to test the association between motivation and BIU. The Chi-square test results revealed no statistically significant association between motivation and BIU, $X^{2}(n=161)=39.748, p=0.939$. These results indicate that motivation plays a minor role in influencing students to utilise their phones for communicating purposes. Finally, hypothesis 3 tested the association between time and BIU mobile phones by students. Results further revealed no statistically significant association between time and BIU, $X^{2}(n=161)=67.527, p=0.391$. The statistical findings reveal that there is no evidence to support hypothesis 3 . The results indicate that time plays a minor role in influencing students to utilise their phones for communication purposes. Based on the findings, a conclusion was reached that student communication via mobile phones is seldom a time-related factor. However, due to the desire to know more, students find themselves downloading more features (Potgieter 2015) and exploring various other features installed on their phones at great length and with enthusiasm independent of time.

\section{Discussion}

The presence of various mobile phone features appears to heighten the intention to use mobile phones. Therefore, this study concurs with other empirical studies, for example, those by Li et al. (2012), Ilechukwu (2013) and Nwogu et al. (2014), which concluded that the greater the amount of features on a mobile phone, the higher the behavioural intention to utilise that device for various communicating purposes. Uniquely in this study, this happens within a South African TVET setting, a notion which no other studies have explored before. The findings of this study are also in line with the assumptions of the economic theory suggesting that product features and attributes are linked to consumer demand given the additive utility function. Results further revealed no statistically significant association between motivation and BIU. Earlier on, in accordance with empirical evidence, it was argued that motivational factors are those that move individuals to use their phone (Qualasvirta 2005; Van Biljon 2006). This implied that individual motivational needs had to exist as a fundamental technology adoption requirement. Given the findings of this study, and contrary to literature, it can be argued that modern mobile phones are, themselves, a motivational tool. In this era of smartphones, mobile phones do more than work as a communication device but also as a tool to support the learner in realising his or her potential. For example, the use of modern mobile phones has proven to offer new educational opportunities. Thus, the use of smartphones or mobile phones in TVET has a positive effect on learning and cultivating the desire to learn. It is widely acknowledged that not all students respond to the new institution's settings (a new environment of learning and/or teaching techniques) in the same manner. Some students find it hard to adjust to the new environment and/or teaching techniques, but with the use of smartphones, students play a significant role in their own learning in various and rewarding methods. With mobile phones in their hands, students have realised, nurtured and demonstrated skills essential to their success in both academic and professional fields.

\section{Contribution}

A contribution of this study lies in its shift from previous empirical studies with regard to the task complexity theory (Johnson \& Payne 1985). The assumptions of the task complexity theory adopted in this study were that motivation and time can be influenced (negatively) by complexity of the mobile phone as a physical product and its features. As elaborated earlier, the thinking was that the greater the product feature and its complexity, the more consumer effort is needed. Wright (1975) further theorised that consumers usually wish to minimise decision efforts. Therefore, other scholars such as Mick and Fournier (1998) and Dellaert and Stremersch (2005) came to the conclusion that mobile phone features that require much effort and time may be avoided due to their complexity as they trigger anxiety or stress. Thompson et al. (2005) further suggested that complexity or too many features could lead to feature fatigue, thus making a product overwhelming and thereby causing dissatisfaction. The findings of this study, in contrast to the task complexity theory, are that students are very passionate about smartphones as they regard them as tools of their era. More often, students find themselves exploring at great length various features installed in modern mobile phones, thus supporting the view that the more mobile phone features, the higher the BIU.

\section{Implications for theory}

Based on the findings, the research contributes to literature on education and technology, communication as well as marketing. The assumptions of the task complexity theory stating that consumers will avoid complex products were not supported in this study. Phones with more features qualify to be regarded as complex products and resultantly, making use of such phones is also a complex task. On the contrary, students were found to be comfortable in utilising complex products, as evident in higher ratings of BIU. 


\section{Implications for practice}

The findings of this study provide evidence and data that can be used by practitioners with interest in technology usage by students. The findings reveal that owing to various features on smartphones, students now have access to the Internet. Estimates by the Groupe Speciale Association (GSMA 2014) suggest that between the year 2014 and 2020, sub-Saharan Africa will realise an exponential growth unlike any region, globally, with regard to connectivity through smartphones. Around 525000000 connections will be through smartphones, making it the most convenient gadget to conclude business and personal transactions via the Internet. Hence, marketers of educational material can exploit this function and target student groups making use of platforms such as social networking features found on mobile devices for the purpose of advertising.

Given that mobile phone features were found also to be associated with BIU, communication experts can utilise interactive features to gather insights on ever-changing consumer tastes and preferences among youth. In addition, Mukherjee and Hoyer (2001) point out that products which are a result of high innovation such as smartphones, as evident by thevolume of application software which they can accommodate, can create a competitive advantage that help marketers to penetrate the student and/or youth market easily. The findings of this study serve as an eye opener to various practitioners with varying interests. For example, the South African student market, largely representing the youth, adopts products that promote interaction between peers in the same manner as other regional and international markets. Hence, to marketers of mobile phones who would like to pursue global and regional markets, the local market's behaviour can prove to be a useful secondary research platform.

\section{Limitations}

A limitation exists with the present research. The results of this research are not generalisable to the entire population of TVET students in South Africa. Caution should be exercised when interpreting and making implications based on this.

\section{Future research}

Despite the limitation that exists with the current research, future research can be suggested to improve on such. Furthermore, a qualitative study would aid in understanding underlying motivations for mobile phone usage among students.

\section{Conclusion}

The use of mobile phones outside communication purposes can bring added value to the TVET system in South Africa. Thus, if the responsible authorities in the TVET sector adopt the relevant framework and incorporate the use of communication application software (Facebook, Twitter, LinkedIn, WhatsApp, Skype, Viber and BBM among others) that come along with modern mobile phones into the TVET system, such software can prove to be of great use in the form of student support and guiding tools.

\section{Acknowledgements Competing interests}

The authors declare that they have no financial or personal relationships which may have inappropriately influenced them in writing this article.

\section{Authors' contributions}

H.S. was the project leader assisted by A.S. W.C. was responsible for the data collection and assisted H.S. with the data analysis. H.S. and W.C. were involved in the final write up of the project.

\section{References}

Agundo-Peregrina, Á.F., Hernández-García, A. \& Pascual-Miguel, F.J., 2014, 'Behaviora intention, use behavior and the acceptance of electronic learning systems: Differences between higher education and lifelong learning', Computers in Human Behavior 34, 301-314. http://dx.doi.org/10.1016/j.chb.2013.10.035

Ajzen, I. \& Fishbein, M., 1980, Understanding attitudes and predicting social behaviour, Prentice-Hallm, Englewood Cliffs, NJ.

Babbie, E., 1992, The practice of social research, Belmont, Wadsworth, $\mathrm{OH}$.

Bandura, A., 1986, Social foundations of thought and action: A social cognitive theory, Prentice-Hall, Englewood Cliffs, NJ.

Baysal, Z.N., Sahenk, S.S. \& Hazneci, Y.O., 2010, 'Evaluation of the primary school level students' attitudes towards mobile phones', Procedia Social and Behavioral Sciences 2, 4279-4284. http://dx.doi.org/10.1016/j.sbspro.2010.03.679

Caronia, L. \& Caron, A.H., 2004, 'Constructing a specific culture: Young people's use of the mobile phone as a social performance', Convergence: The International Journal of Research into New Media Technologies 10(2), 28-61. http://dx.doi. org/10.1177/135485650401000204

Chen, S.H., Li, S.H. \& Li C.Y., 2011, 'Recent related research in technology acceptance model: A literature review', Australian Journal of Business and Management Research 1(9), 124-127.

Chen, Y.F. \& Katz, J.E., 2009, 'Extending family to school life: College students' use of the mobile phone', International Journal of Human-Computer Studies 67(2), 179-191. http://dx.doi.org/10.1016/j.ijhcs.2008.09.002

Chinyamurindi, W. \& Shava, H., 2015, 'An investigation into e-learning acceptance and gender amongst final year students', South African Journal of Information Management 17(1), 1-9. http://dx.doi.org/10.4102/sajim.v17i1.635

Chinyamurindi, W.T. \& Louw, G.J., 2010, 'Gender differences in technology acceptance in selected South African companies: Implications for electronic learning: Original research', SA Journal of Human Resource Management 8(1), 1-7. http://dx.doi org/10.4102/sajhrm.v8i1.204

Chua, J.H. \& Jamil, H., 2012, 'Factors influencing the Technological Pedagogical Content Knowledge (TPACK) among TVET instructors in Malaysian TVET institution', Procedia Social and Behavioral Sciences 69, 1539-1547. http://dx.doi. org/10.1016/j.sbspro.2012.12.096

Clark, L.A. \& Watson, D., 1995, 'Constructing validity: Basic issues in scale development', Psychological Assessment 7, 309-319. http://dx.doi.org/10.1037/ 1040-3590.7.3.309

Compeau, D.R. \& Higgins, C.A., 1995, 'Computer self-efficacy: Development of a measure and initial test', MIS Quarterly 19(2), 189-211. http://dx.doi.org/ $10.2307 / 249688$

Creswell, J.W., 2013, Qualitative inquiry \& research design: Choosing among five approaches. 3rd edn., Sage, Thousand Oaks, CA.

Creswell, J.W., 2014, Research design: Qualitative, quantitative and mixed methods approaches, 4th edn., Sage, Thousand Oaks, CA.

Davis, F., 1989, 'Perceived usefulness, perceived ease of use, and user acceptance of information technology', MIS Quarterly 13(3), 318-339. http://dx.doi.org/10. $2307 / 249008$

Dellaert, B.G.C. \& Stremersch, S., 2005, 'Marketing mass-customized products: Striking a balance between utility and complexity', Journal of Marketing Research XLII May, 219-227. http://dx.doi.org/10.1509/jmkr.42.2.219.62293

Desmet, K. \& Parente S., 2012, 'The evolution of markets and the revolution of industry: A unified theory of growth', Journal of Economic Growth 17(3), 205-234. $\mathrm{http}: / / \mathrm{dx}$.doi.org/10.1007/s10887-012-9080-y

Economicides, A.A. \& Grouspoulou, A., 2009, 'Students thoughts about the importance and costs of their mobile devices features and services', Telematics Inform 26, 57-84. http://dx.doi.org/10.1016/j.tele.2008.01.001 
Eteokleous, N. \& Ktoridou, D., 2009, 'Investigating mobile devices integration in highe education in Cyprus: Faculty perspectives', International Journal of Interactive Mobile Technologies 3(1), 38-48. http://dx.doi.org/10.3991/ijim.v3i1.762

Field, A., 2013, Discovering statistics using IBM SPSS statistics, 4th edn., Sage, London.

Fishbein, M. \& Ajzen, I., 1975, Belief, attitude, intention, and behaviour: An introduction to theory and research, Addison-Wesley, Reading, MA

Fisher, G., Jaff, R., Powell, L., \& Hall, G., 2003, 'Public further education and training colleges', in Human Research Council (Ed.) Human Resources Development Review 2003: Education, employment and skills in South Africa, HSRC Press, Cape Town HSRC and East Lansing; Michigan State University Press.

Gredler, M.E., Broussard, S.C. \& Garrison, M.E.B., 2004, 'The relationship between classroom motivation and academic achievement in elementary school aged children', Family and Consumer Sciences Research Journal 33(2), 106-120. http:// dx.doi.org/10.1177/1077727X04269573

GSMA, 2014, The mobile economy: Sub-Saharan Africa 2014, viewed 21 Octobe 2015, from http://ssa.gsmamobileeconomy.com/

Guay, F., Chanal., J., Ratelle, C.F., Marsh, H.W., Larose, S. \& Boivin, M., 2010, 'Intrinsic, identified, and controlled types of motivation for school subjects in youns elementary school children', British Journal of Educational Psychology 80(4), 711-735. http://dx.doi.org/10.1348/000709910x499084

Hakoama, M. \& Hakoyama, S., 2011, 'The impact of cell phone use on social networking and development among college students', American Association of Behavioral and Social Sciences Journal 15, 1-20.

Head, M. \& Ziolkowski, N., 2012, 'Understanding student attitudes of mobile phone features: Rethinking adoption through conjoint, cluster and SEM analyses', Computers in Human Behavior 28(6), 2331-2339. http://dx.doi.org/10.1016/j. chb.2012.07.003

Hsiao, C.H. \& Yang, C., 2011, 'The intellectual development of the technology acceptance model: A co-citation analysis', International Journal of Information Management 31(2), 128-136. http://dx.doi.org/10.1016/j.ijinfomgt.2010.07.003

Ilechukwu, L.C., 2013, 'The assessment of utilisation of e-learning opportunities for effective teaching and learning of religion in Nigerian tertiary institutions', European Journal of Educational Studies 5(3), 343-359.

Jack, B. \& Clarke, A., 1998, 'The purpose and the use of questionnaires in research', Professional Nurse 14(3), 176-179.

Jamal, A., Sedie, R., Haleem, K.A. \& Hafiz, N., 2012, 'Patterns of use of "smart phones" among female medical students and self-reported effects', Journal of Taibah University Medical Sciences 7(1), 45-49. http://dx.doi.org/10.1016/j.jtumed. 2012.07.001

Johnson, E.J. \& Payne, J.W., 1985, 'Effort and accuracy in choice', Management Science 31(3), 395-414. http://dx.doi.org/10.1287/mnsc.31.4.395

Jokela, T., 2004, 'When good things happen to bad products: Where are the benefits of usability in the consumer appliance market?', Interactions 11(6), 28-35. http:// dx.doi.org/10.1145/1029036.1029050

Jurisic, B. \& Azevedo, A., 2011, 'Building customer-brand relationships in the mobile communications market: The role of brand tribalism and brand reputation', Brand Management 18(4/5), 349-366. http://dx.doi.org/10.1057/bm.2010.37

Kang, S., 2014, 'Factors influencing intention of mobile application use', International Journal of Mobile Communications 12(4), 360-379. http://dx.doi.org/10.1504/ IJMC.2014.063653

Karim, A., Darus, S.H. \& Hussin, R., 2006, 'Mobile phone applications in academic library services: A students' feedback survey', Campus-Wide Information Systems 23(1), 35-51. http://dx.doi.org/10.1108/10650740610639723

Katz, J.E., 2006, 'Mobile communication and the transformation of daily life: The nex phase of research on mobiles', Knowledge, Technology \& Policy 19(1), 63-71. http://dx.doi.org/10.1007/s12130-006-1016-4

Keeton, K.E., 2008, 'An extension of the UTAUT model: How organizational factors and individual differences influence technology acceptance', PhD Dissertation, University of Houston.

Kyobe, M.E. \& Shongwe, M.M., 2011, 'Investigating the extent to which mobile phones reduce knowledge transfer barriers in student project teams', South African Journal of Information Management 13(1), 1-10. http://dx.doi.org/ 10.4102/sajim.v13i1.424

Lancaster, K., 1971, Consumer demand: A new approach, Columbia University Press, New York.

Lee, D.Y. \& Lehto, M.R., 2013, 'User acceptance of YouTube for procedural learning: An extension of the Technology Acceptance Model', Computers and Education 61 193-208. http://dx.doi.org/10.1016/j.compedu.2012.10.001

Lepp, A., Barkley, J.E., Sanders, G.J., Rebold, M. \& Gates, P., 2013, 'The relationship between cell phone use, physical and sedentary activity, and cardiorespiratory fitness in a sample of U.S. college students', International Journal of Behavioural Nutrition and Physical Activity 10, 79. http://dx.doi.org/10.1186/1479-5868$10-79$

Lepp, A., Li, J., Barkley, J.E. \& Salehi-Esfahani, S., 2015, 'Exploring the relationships between college students' cell phone use, personality and leisure', Computers in Human Behaviour 43, 210-219. http://dx.doi.org/10.1016/j.chb.2014.11.006

Li, B., Yang, J., Song, X. \& Lu, B., 2012, 'Survey on disposal behaviour and awareness of mobile phones in Chinese university students', Procedia Environmental Sciences 16, 469-476. http://dx.doi.org/10.1016/j.proenv.2012.10.064
Lightner, R., Benander, R. \& Kramer, E.F., 2008, Faculty and student attitudes about transfer of learning, viewed 11 February 2015, from http://www.insightjournal. net/Volume3/FacultyStudentAttitudesTransferLearning.pdf

Ling, R., 2004, The mobile connection: The cell phone's impact on society, Morgan Kaufmann Publishers, San Francisco, CA.

Mannell, R.C., 2007, 'Leisure, health and well-being', World Leisure Journal 49(3), 114-128. http://dx.doi.org/10.1080/04419057.2007.9674499

Mick, D.G. \& Fournier, S., 1998, 'Paradoxes of technology: Consumer cognizance, emotions, and coping strategies', Journal of Consumer Research 25, 123-143. http://dx.doi.org/10.1086/209531

Mukherjee, A. \& Hoyer, W.D., 2001, 'The effect of novel attributes on product evaluation', Journal of Consumer Research 28, 462-472. http://dx.doi.org/10.1086/323733

Nwogu, U.F., Udoye, N.R. \& Oguejiofor, C.S., 2014, 'Towards utilisation of e-learning in preparing business education students for the world of work', African Education preparing business education students for the world of work',
Review 8(3), 155-164. http://dx.doi.org/10.4314/afrrev.v8i3.13

Ong, C.S. \& Lai, J.Y., 2006, 'Gender differences in perceptions and relationships among dominants of e-learning acceptance', Computers in Human Behaviour 22(5), 816-829. http://dx.doi.org/10.1016/j.chb.2004.03.006

Pallant, J., 2010, SPSS survival manual: A step by step guide to data analysis using SPSS, 4th edn., McGraw-Hill, Maidenhead.

Park, S.Y., 2009, 'An analysis of the technology acceptance model in understanding university students' behavioural intention to use e-learning', Educational Technology and Society 12(3), 150-162.

Peters, O., Rickes, M., Jockel, S., Von Criegerna, C. \& Van Deursen, A., 2006, 'Explaining and analyzing audiences: A social cognitive approach to selectivity and media use', Communications 31, 279-308. http://dx.doi.org/10.1515/COMMUN.2006.019

Philips, D.C. \& Burbules, N.C., 2000, Postpositicism and educational research, Rowman \& Littlefield, Lanham, MD.

Potgieter, A., 2015, 'The mobile application preferences of undergraduate university students: A longitudinal study', South African Journal of Information Management $17(1), 650$.

Pourrazavi, S., Allahverdipour, H., Jafarabadi, M.S. \& Matlabi, H., 2014, 'A sociocognitive inquiry of excessive mobile phone use', Asian Journal of Psychiatry 10 84-89. http://dx.doi.org/10.1016/j.ajp.2014.02.009

Qualasvirta, A., 2005, 'Grounding the innovation of future technologies', Human Technology 1(1), 58-75. http://dx.doi.org/10.17011/ht/urn.2005126

Saadé, R.G., Nebebe, F. \& Tan, W., 2007, 'Viability of the technology acceptance model in multimedia learning environments: A comparative study', Interdisciplinary Journal of Knowledge and Learning Objects 3(1), 175-184.

Salesforce Marketing Cloud, 2014, 2014 mobile behaviour report, viewed 15 October 2015, from http://www.exacttarget.com/2014-mobile-behavior-report

Skiba, D.J., 2014, 'The connected age: Mobile apps and consumer engagement', Nursing Education Perspectives 35(3), 199-201. http://dx.doi.org/10.5480/1536-5026-35. 3.199

Streiner, D.L., 1993, 'A checklist for evaluating the usefulness of rating scales', Canadian Journal of Psychiatry 38(2),140-148. PMid:8467441

Thompson, D.V., Hamilton, R.W. \& Rust, R.T., 2005, 'Feature fatigue: When product capabilities become too much of a good thing', Journal of Marketing Research XLII, November, 431-442. http://dx.doi.org/10.1509/jmkr.2005.42.4.431

Ting, D.H., Lim, S.F., Patanmacia, T.S., Low, C.G. \& Ker, G.C., 2011, 'Dependency on smartphone and the impact on purchase behaviour', Young Consumers: Insight and Ideas for Responsible Marketers 12(3), 193-203. http://dx.doi. org/10.1108/17473611111163250

Van Biljon, J.A., 2006, 'A model for representing the motivational and cultural factors that influence mobile phone usage variety', Doctoral Dissertation, viewed 3 January 2015, from http://uir.unisa.ac.za/xmlui/bitstream/handle/10500/2149/ thesis.pdf?sequence=1

Venkatesh, V. \& Davis, F.D., 1996, 'A model of the antecedents of perceived ease of use: Development and test', Decision sciences 27(3), 451-481. http://dx.doi. org/10.1111/j.1540-5915.1996.tb00860.x

Venkatesh, V. \& Davis, F.D., 2000, 'A theoretical extension of the technology acceptance model: Four longitudinal field studies', Management Science 46(2), acceptance model: Four longitudinal field studies', Manager

Walsh, S.P., White, K.M. \& Young, R., 2010, 'Needing to connect: The effect of self and others on young people's involvement with their mobile phones', Australian Journa of Psychology 62(4), 194-203. http://dx.doi.org/10.1080/00049530903567229

Wanajak, K., 2011, 'Internet use and its impact on secondary school students in chainmail, Thailand', PhD Thesis, Edith Cowan University, Australia.

Wang, Y.S., Lin, H.H. \& Luarn, P., 2006, 'Predicting consumer intention to use mobile service', Information Systems Journal 16, 157-179. http://dx.doi.org/10.1111/ j.1365-2575.2006.00213.x

Wiid, J. \& Diggines, C., 2013, Marketing research, 2nd edn., Juta, Cape Town.

Wright, P., 1975, 'Consumer choice strategies: Simplifying vs. optimizing', Journal of Marketing Research 12, 60-67. http://dx.doi.org/10.2307/3150659

Zhang, P. \& von Dran, G.M., 2000, 'Satisfactor and dissatisfactorers: A two-factor model for website design and evaluation', Journal of the American Society for Information Science 51(4), 1253-1268, http://dx.doi.org/10.1002/1097-4571 (2000)9999:9999<::AID-ASI1039>3.0.CO;2-O 